\title{
A Green and Simple Technique for Flotation and Spectrophotometric Determination of Cobalt(II) in Pharmaceutical and Water Samples
}

\author{
Magda Ali Akl* and Wegdan Sasi Ahmed Alharwi \\ Chemistry Department, Faculty of Science, Mansoura University, Mansoura, Egypt.
}

\begin{abstract}
T THE PRESENT study, a green and simple technique has been used for the preconcentration, flotation and spectrophotometric detection of $\mathrm{Co}$ (II) in pharmaceutical and water samples is established. At $\mathrm{pH} 4$, the chromogenic reagent 4-(2pyridyl azo) resorcinol (NaPAR) reacts with $\mathrm{Co}(\mathrm{II})$ to form a pink 1:2 (M:L) complex in aqueous solution. This complex has been successfully separated by flotation using the anionic surfactant, oleic acid(HOL). The concentration of $\mathrm{Co}(\mathrm{II})$ in the scum layer was determined easily by spectrophotometry at $510 \mathrm{~nm}$. The parameters that influence the flotation and spectrophotometric determination of Co(II) were studied. Beer's law was obeyed over a concentration range 0.01-0.32 $\mu \mathrm{g} \mathrm{mL}^{-1}$ in the aqueous as well as in the scum layer. The molar absorptivity of the $\mathrm{Co}$ (II)-NaPAR in the aqueous and scum layer was found to be $1.2 \times 10^{4} \mathrm{~L} \mathrm{~mol}^{-1} \mathrm{~cm}^{-1}$ and $1.54 \times 10^{5} \mathrm{~L} \mathrm{~mol}^{-1} \mathrm{~cm}^{-1}$, respectively. The detection limit of the proposed technique, the recovery $\%(\mathrm{R} \%)$ and the relative standard deviation(RSD\%) are $3.09 \mathrm{ngmL}^{-1}, 98 \%$ and $1.5 \%$, respectively. The method was verified by analysis of real certified samples. The proposed procedure was applied to determine $\mathrm{Co}(\mathrm{II})$ in water, pharmaceutical samples as well as in synthetic mixtures. The mechanism of flotation is proposed.
\end{abstract}

Keywords: Flotation, Preconcentration, Co(II), Spectrophotometry, Pharmaceutical and water samples.

\section{Introduction}

Due to the continuous industrial development, many studies were recently focused on the treatments of the industrial wastes. One of the most important industrial wastes, which mainly cause water pollution, is the heavy metal ions such as mercury, copper, cobalt, cadmium and palladium. These heavy metals are able to cause serious problems to human, animal and plant life when released into the environment[1].

Cobalt is an essential element for the functioning of many vital processes. It is extremely important in the processes of blood formation, stimulation of hemoglobin synthesis, and the functioning of vitamins, enzymes and hormones. This metal has a very positive influence on the metabolism of vitamins, such as ascorbic acid and vitamin $B_{12}$. Cobalt is an essential element in the human body as a component of vitamin $\mathrm{B}_{12}$. Vitamin $\mathrm{B}_{12}$, also called cobalamin, is a water soluble vitamin that has a key role in the normal functioning of the brain and nervous system, and the formation of red blood cells. It is involved in the metabolism of every cell of the human body, especially affecting DNA synthesis, fatty acid and amino acid metabolism [2]

Cobalt and its compounds are used in many processes and products. They are used in the hard metal industry; specialist alloy foundries; cobalt refineries; manufacturing cobalt pigments; chemical factories; manufacturing magnets; pigments in pottery, glass, ceramics and paints. Short-term side effects of exposure to cobalt can include vomiting and abdominal pain if cobalt salts are ingested.

Separation and determination of cobalt from associated elements are indispensable. Due to the low concentration of the heavy metals in the environmental and biological samples and interfering effects, a preconcentration/separation technique is generally necessary prior to the determination. For this purpose, various analytical 
procedures have been used, such as adsorption on activated carbon[3,4], co-precipitation[5],column extraction[6], ion-selective electrode[7,8], liquid-liquid extraction(LLE)[9], cloud point extraction[10] and flotation [11-13].

Flotation has attracted considerable attention mainly because it complies with the "Green Chemistry" principles [14], as the amount of organic solvent is much less than that of traditional liquid extraction [14]. The surfactants used in this technique have very low toxicity compared to the solvents used in the conventional liquid extraction. Moreover, this technique is easy, cheap, incredibly effective, and speedy. Surfactants supported separation via flotation has been used for micro-determination of various heavy metals from environmental samples [15].

The objective of the present study is to introduce 4-(2pyridyl azo) resorcinol, sodium salt (NaPAR) as a brand new flotation collector for $\mathrm{Co}$ (II) in media of diverse sources. In this work, trace quantities of $\mathrm{Co}$ (II) have been transformed to $\mathrm{Co}$ (II)-NaPAR chelate by adding PAR after which the complex in aqueous solution was once rendered hydrophobic using oleic acid (HOL) surfactant. This complex was floated to the scum layer by way of energetic shaking. The concentration of Co(II) used to be decided spectrphotometrically and confirmed by flame atomic absorption spectrometry (AAS). The various experimental parameters that can affect the flotation and spectrophotometric determination of cobalt(II) have been thoroughly studied.

\section{Experimental}

Chemicals and solutions

The chemicals which were used are of analytical reagent grade. Doubly distilled water (DDW) was used.

A stock solution of Cobalt $(1 \mathrm{mg} / \mathrm{mL})$ was prepared by dissolving $\mathrm{CoCl}_{2}$ in $\mathrm{DDW}$ and few drops of concentrated nitric acid were added. Mono sodium salt of 4-(2-pyridylazo) resorcinol, NaPAR, was purchased from Sigma Aldrich. Stock solution $\left(1 \times 10^{-3} \mathrm{molL}^{-1}\right)$ was prepared by dissolving the required amount of NaPAR in DDW. Oleic acid stock solution $\left(6.36 \times 10^{-2} \mathrm{molL}^{-1}\right)$ was prepared by dispersing $20 \mathrm{~mL}$ of HOL (food grade sp.gr.0.895 provided by J.T. Baker Chemical Co.), in one liter of kerosene. Vitamin $B_{12}$ ampoules were analyzed to determine the cobalt content in each drug sample using the proposed methodology. Exactly one $\mathrm{mL}$ of each drug sample was taken and heated in $5 \mathrm{~mL}$ of concentrated $\mathrm{HNO}_{3}$ for dissolution. The cold solution was filtered, collected in a $50-\mathrm{mL}$ calibrated flask and completed to the mark with DDW. To verify the accuracy and applicability of proposed flotation procedure, two reference standard materials (lead-zinc sulphide ore-OCrO (COD 161-96) and stream sediment SARM 52) were analyzed. Various water samples from different origins, e.g. Tap, Nile river and sea water samples were spiked with different amounts of $\mathrm{Co}$ (II) and the flotation procedures were employed for determination of the recovery of the analyte in these water samples

\section{Instrumentation}

Two types of flotation cells were used throughout this work, as has already been described [16]. Flotation cell(a) is a cylindrically graduated glass tube of $16 \mathrm{~mm}$ inner diameter and $290 \mathrm{~mm}$ length with a stopcock at the bottom. Such cell is used to study the different factors affecting the efficiency of flotation. Flotation cell(b) is a cylindrical tube of $6 \mathrm{~cm}$ inner diameter and $45 \mathrm{~cm}$ length with a stop cock at the bottom and a quick fit stopper at the top. This cell is used to separate cobalt from 1 liter of different water samples. Unicam UV2100 UV/vis and MATTSON 5000 FTIR and Perkin-Elmer 2380 atomic absorption spectrometers with an air-acetylene flame were used to record the spectral data and the atomic absorption measurements. Hanna Instruments 8519 digital $\mathrm{pH}$ meters were used to measure the $\mathrm{pH}$ values of sample solutions.

\section{Analytical procedures}

Defined amount (specified for each investigation) of both $\mathrm{Co}$ (II) and the reagent (NaPAR) were mixed. Acetate buffer was used to adjust the $\mathrm{pH}$ of mixture to 4 . The solution was then transferred quantitatively to the flotation cell(type a) and completed to $20 \mathrm{~mL}$ with DDW. The cell was shaken well for few seconds, to ensure complete complexation. ThreemL of HOL (having defined concentration) and still below the critical micelle concentration (CMC), were added, to this solution. The flotation cell was then inverted upside down for few minutes by hand. After $10 \mathrm{~min}$, to ascertain complete flotation, the concentration of the metal ion in the scum was determined spectrophotometrically.

To confirm the results obtained spectrophotometrically, the concentration of $\mathrm{Co}(\mathrm{II})$ in the mother liquor was determined by AAS. 
The floatability (F, \%) [14], of Co(II) was determined from its concentration in the scum using the relation:

$$
\mathrm{F}=\left\{\mathrm{C}_{\mathrm{S}} / \mathrm{C}_{\mathrm{i}}\right\} \times 100 \%
$$

Where $c_{i}$ and $c_{s}$, are the initial and scum concentrations of the analyte, respectively.

\section{Results and Discussion}

\section{Absorption spectra}

Figure 1 illustrates the absorption spectra of the ligand NaPAR(curve a), the Co(II)NaPAR complex in the aqueous solution(curve b) and in the scum layer(curve c). As it can be noticed maximum absorption of the ligand is at $\lambda_{\max } 400 \mathrm{~nm}$. On the other hand, the $\mathrm{Co}(\mathrm{II})-\mathrm{NaPAR}$ chelates formed in the aqueous and in the scum layer have maximum absorbance at $510 \mathrm{~nm}$. The absorbance of $\mathrm{Co}(\mathrm{II})-\mathrm{NaPAR}$ in the HOL layer (curve c) is greater than that of $\mathrm{Co}(\mathrm{II})-\mathrm{NaPAR}$ in the aqueous solution (curve b). This finding denotes the beneficial effect of HOL surfactant in separation of $\mathrm{Co}$ (II) ions to the scum layer.

\section{Effect of Experimental variables}

Influence of $\mathrm{pH}$

The effect of $\mathrm{pH}$ on the flotation of $2 \times 10^{-}$ ${ }^{5} \mathrm{molL}^{-1}$ metal with $1 \times 10^{-4} \mathrm{molL}^{-1} \mathrm{HOL}$ in the absence and presence of $1 \times 10^{-4} \mathrm{molL}^{-1} \mathrm{NaPAR}$ was studied in the $\mathrm{pH}$ values ranging from 2.0 to 9.0 using alkalinated acetate buffer. The results are shown in Fig. 2. In the absence of NaPAR (graph a), the flotation efficiency of $\mathrm{Co}$ (II) is very low over the $\mathrm{pH}$ range tested. Such a separation percent is not analytically good in which Co(II) floats as Co-oleate [12]. On the addition of the ligand, the flotation efficiency reached its maximum $(\sim 100 \%)$ over the $\mathrm{pH}$ values that range from 3.0 to 5.0.

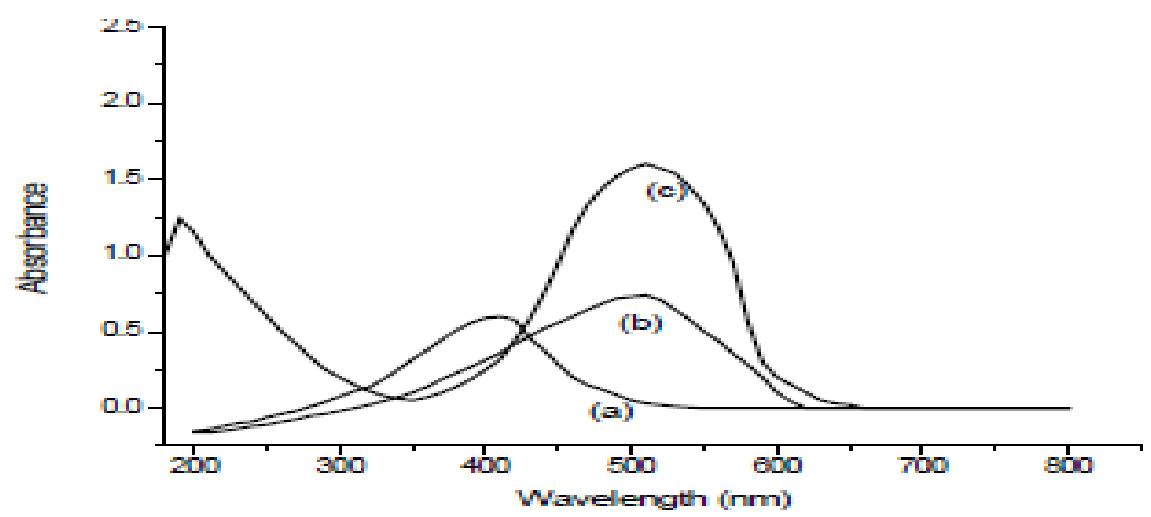

Fig. 1. Absorption spectra of: a) The reagent NaPAR, b) Co-NaPAR complex in aqueous solution and c) CoNaPAR in the scum layer

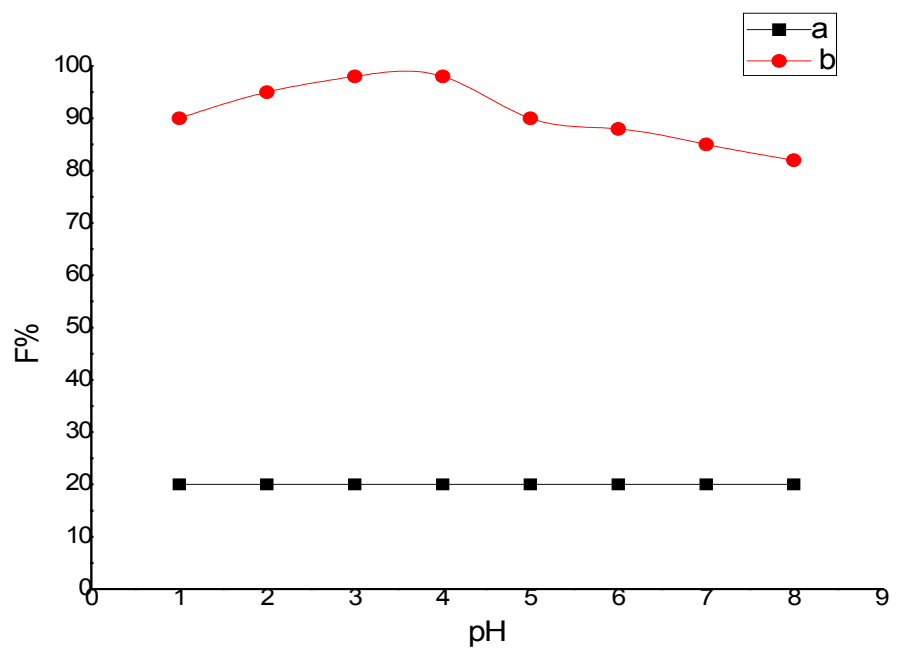

Fig.2. Effect of the pH on the separation efficiency of $2 \times 10^{-5} \mathrm{molL}^{-1} \mathrm{Co}(\mathrm{II})$ a) in the absence of NaPAR, b) in the presence of $2 \times 10^{-4} \mathrm{molL}^{-1} \mathrm{NaPAR}$, using $2 \times 10^{-4} \mathrm{molL}^{-1} \mathrm{HOL}$. 
Influence of oleic acid (HOL) concentration

The influence of HOL concentration on the flotation percentage $(\mathrm{F}, \%)$ of $\mathrm{Co}(\mathrm{II})$ in the presence and absence of NaPAR is represented in Fig 3. As it can be noticed, maximum flotation $\%$ of $\mathrm{Co}$ (II) $100 \%$ was successfully obtained over a large scale of HOL concentration $\left(2 \times 10^{-4}-0.5 \times 10^{-}\right.$ $\left.{ }^{2} \mathrm{molL}^{-1}\right)$ in the presence of $\mathrm{NaPAR}\left(1 \times 10^{-4} \mathrm{molL}^{-1}\right)$, Fig. 3. A suitable concentration of HOL $\left(2 \times 10^{-}\right.$ ${ }^{4} \mathrm{molL}^{-1}$ ) was used throughout this study.

\section{Influence of ligand concentration}

The influence of the concentration of NaPAR ligand on the flotation $\%$ of $2.0 \times 10^{-5} \mathrm{molL}^{-1} \mathrm{Co}(\mathrm{II})$ ion using $2.0 \times 10^{-4} \mathrm{molL}^{-1} \mathrm{HOL}$ surfactant at $\mathrm{pH}$ 4, is shown in Fig. 4. As it is clearly evident in Fig. 4 graph a, the flotation $\%$ of $\mathrm{Co}$ (II) in the absence of NaPAR doesn't exceed $20 \%$. On the other hand, the Flotation \% starts to increase gradually upon the addition of NaPAR amount until it reaches its maximum $100 \%$ at $4.0 \times 10$ ${ }^{5} \mathrm{moll}^{-1} \mathrm{NaPAR}$ at a ratio of $1: 2 \mathrm{Co}(\mathrm{II})$ : NaPAR. The flotation $\%$ remains stationary upon further addition of NaPAR. This allowed the use of the proposed procedure to analyze $\mathrm{Co}(\mathrm{II})$ in media of unknown concentration.

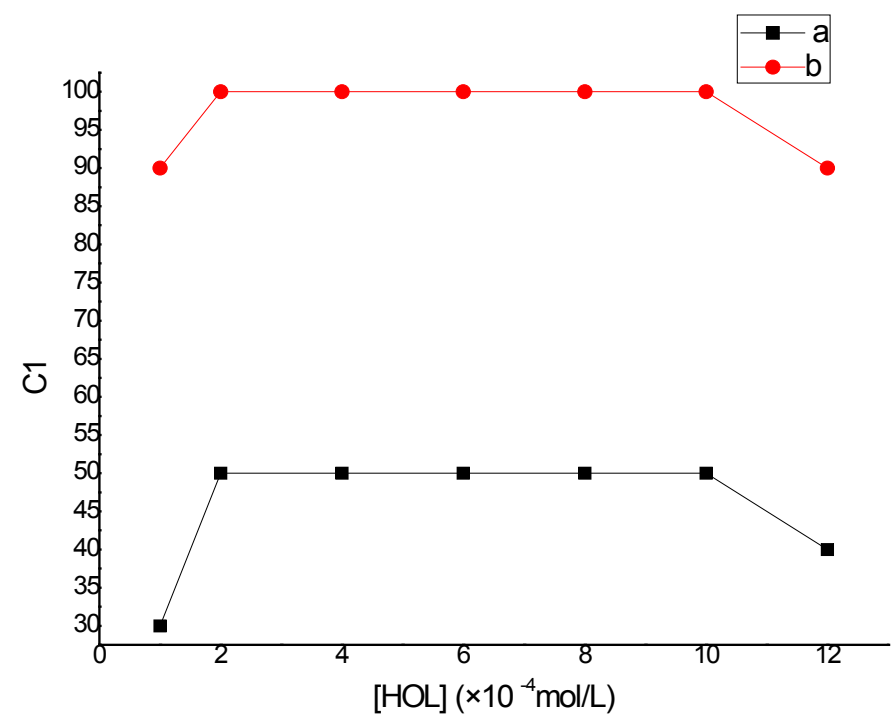

Fig. 3. Floatability of $\mathrm{Co}(\mathrm{II}), 2 \times 10^{-5} \mathrm{molL}^{-1}$ vs. HOL concentration: a) in the absence of NaPAR and b) in the presence of $2 \times 10^{-4} \mathrm{molL}^{-1} \mathrm{NaPAR}$ at $\mathrm{pH} 4$.

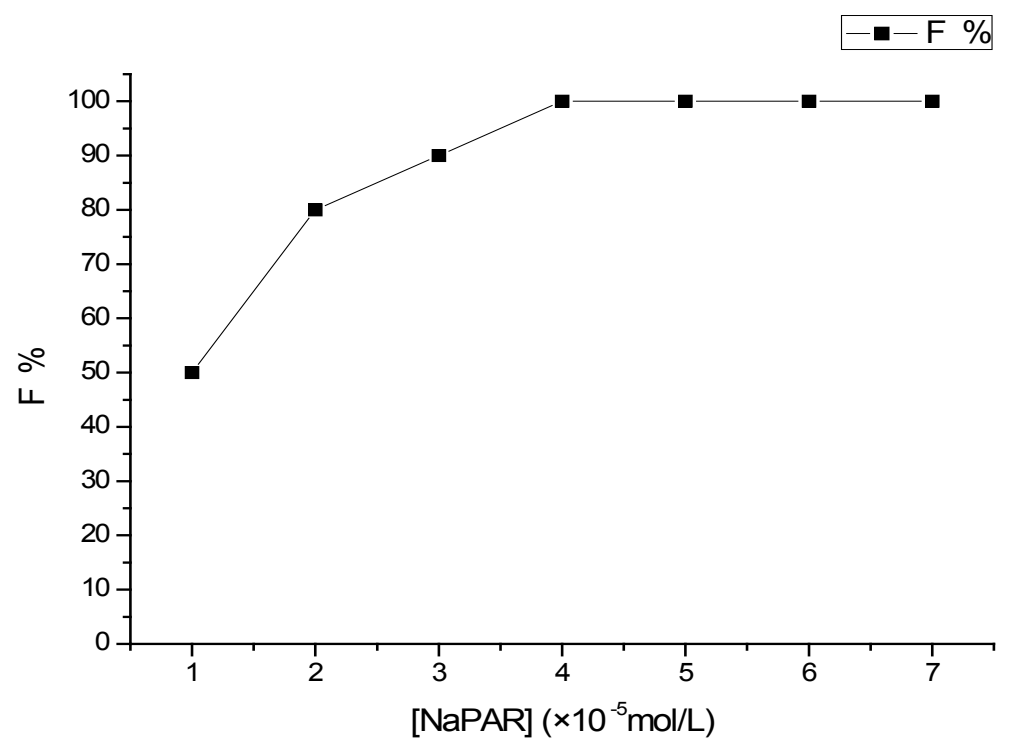

Fig. 4. Floatability of $2 \times 10^{-5} \mathrm{molL}^{-1}$ of $\mathrm{Co}$ (II) at $\mathrm{pH} 4$ in the presence of NaPAR using $2 \times 10^{-4} \mathrm{molL}^{-1} \mathrm{HOL}$ at $\mathrm{pH} 4$. 


\section{Influence of Co(II) concentration}

The influence of the concentration of $\mathrm{Co}$ (II) on the flotation $\%$ in the presence of $4.0 \times 10^{-5} \mathrm{molL}$ ${ }^{1} \mathrm{NaPAR} \operatorname{sing} 2.0 \times 10^{-4} \mathrm{molL}^{-1} \mathrm{HOL}$ surfactant at $\mathrm{pH}$ 4, is shown in Fig. 5. As it is clearly evident in Fig. 5 , the flotation $\%$ starts to increase gradually upon the addition of NaPAR amount until it reaches its maximum $100 \%$ at $2.0 \times 10^{-5} \mathrm{molL}^{-1} \mathrm{Co}(\mathrm{II})$ at a ratio of $1: 2 \mathrm{Co}(\mathrm{II}): \mathrm{NaPAR}$. The flotation $\%$ starts to decrease upon further increase of $\mathrm{Co}$ (II) concentration.

\section{Influence of temperature}

The influence of temperature on the flotation $\%$ of $2.0 \times 10^{-5} \mathrm{molL}^{-1} \mathrm{Co}(\mathrm{II})$ in the presence of $2.0 \times 10^{-}$ ${ }^{4} \mathrm{molL}^{-1} \mathrm{NaPAR}$ and $2.0 \times 10^{-4} \mathrm{molL}^{-1} \mathrm{HOL}$ at $\mathrm{pH} 4$ is provided in Fig. 6. As it can be noticed, the F, $\%$, is not affected upon increasing the temperature up to $80{ }^{\circ} \mathrm{C}$. All subsequent experiments were performed at room temperature, i.e. $25^{\circ} \mathrm{C}$.

\section{Stability of Co(II)-NaPAR complex}

The absorbance of the complex formed in oleic acid was measured at various periods of times to study the stability of the complex. As it is noticed in Fig. 7, the absorbance of the pink colored complex remains stable over more than $60 \mathrm{hr}$.

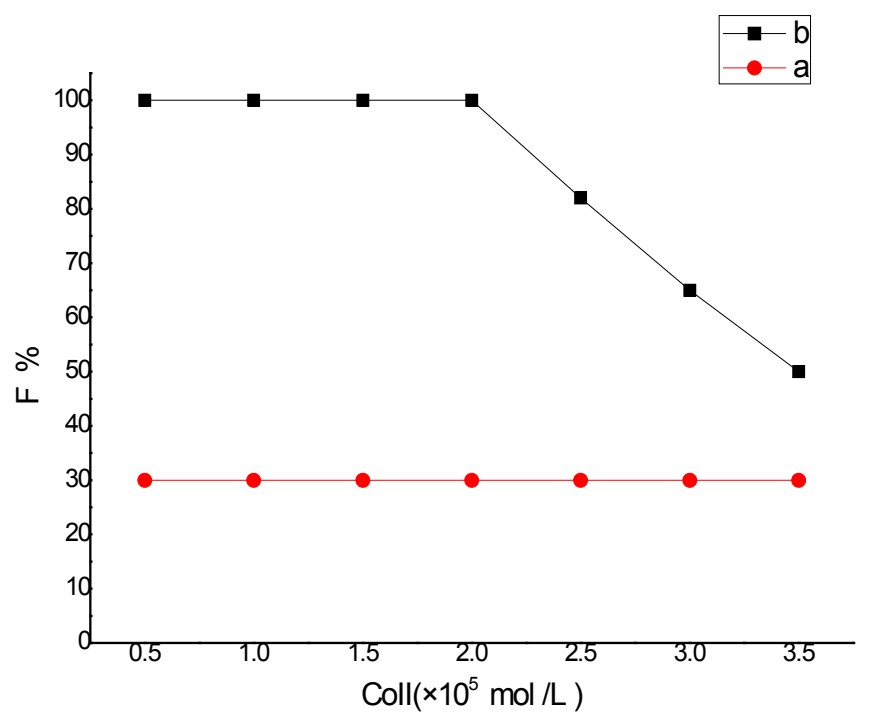

Fig. 5. Floatability of different concentrations of $\mathrm{Co}(\mathrm{II})$ at $\mathrm{pH} 4:$ a) in the absence of $\mathrm{NaPAR}$, b) in the presence of 4x10 ${ }^{-5} \mathrm{molL}^{-1}$ NaPAR using $2 \times 10^{-4} \mathrm{molL}^{-1} \mathrm{HOL}$.

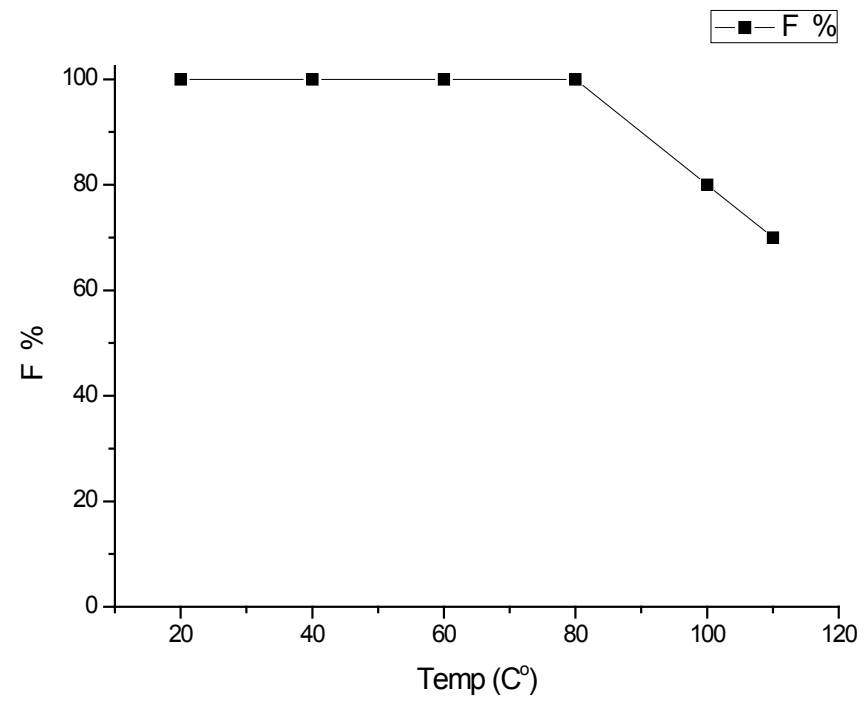

Fig. 6. Effect of temperature on the separation efficiency of $2 \times 10^{-5} \mathrm{molL}^{-1} \mathrm{Co}(\mathrm{II})$ at $\mathrm{pH} 4.0$ in the presence of $4 \times 10^{-4} \mathrm{molL}^{-1}$ NaPAR using $2 \times 10^{-4} \mathrm{molL}^{-1} \mathrm{HOL}$. 


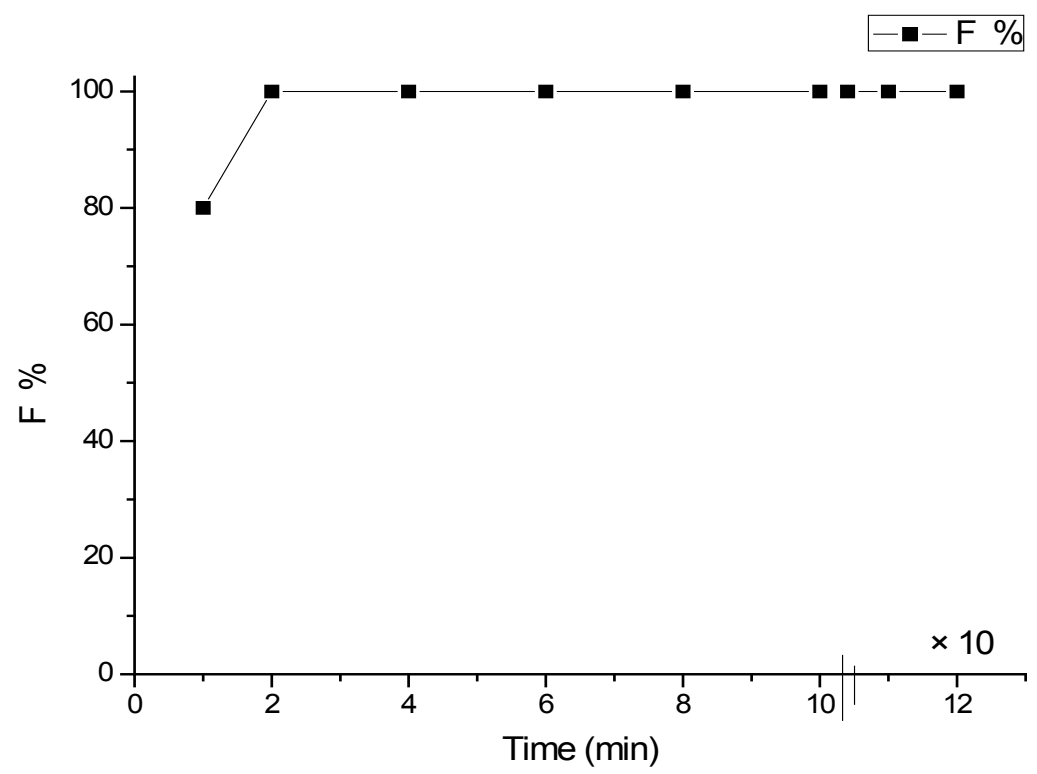

Fig. 7. Effect of time on the separation efficiency of $2 \times 10^{-5} \mathrm{molL}^{-1} \mathrm{Co}(\mathrm{II})$ at $\mathrm{pH} 4.0$ in the presence of $4 \times 10^{-4} \mathrm{molL}^{1}$ NaPAR using $2 \times 10^{-4}$ molL $^{-1}$ HOL.

Influence of volume

Suitable large flotation cells (type b) were used to separate defined concentration of $\mathrm{Co}$ (II) from aqueous samples having large volumes, using the recommended conditions. The results obtained indicated that an amount equal to $100 \mu \mathrm{g}$ of $\mathrm{Co}$ (II) ions can be quantitatively separated from different aqueous volumes up to two liters to $10 \mathrm{~mL} \mathrm{HOL}$. The preconcentration factor is 200 .

\section{Effect of ionic strength}

Table 1 shows the effect of the ionic strength on the flotation $\%(\mathrm{~F} \%)$ of $2.0 \times 10^{-5} \mathrm{molL}^{-1}$ of Co(II)using2.0 x $10^{-4} \mathrm{molL}^{-1} \mathrm{HOL}$ and $4.0 \times 10^{-4}$ molL-1 NaPAR at $\mathrm{pH} 4$. The results obtained indicated that the flotation $\%$ of $\mathrm{Co}$ (II) is not greatly affected by the ionic strength.

\section{Influence of interfering ions}

The effect of interfering metal ions on the flotation $\%$ of $\mathrm{Co}$ (II) ion using the optimum conditions was examined. These foreign ions were selected on the basis that they are normally present in fresh and saline waters. The results (Table 2), showed that most of the tested foreign cations did not interfere in the recovery of $\mathrm{Co}$ (II) ions using the optimum conditions. $1 \mathrm{~mL}$ of 0.05 molL ${ }^{-1} \mathrm{NaS}_{2} \mathrm{O}_{3}$ was added to mask the effect of $\mathrm{Cd}(\mathrm{II})$ while $1 \mathrm{mLof} 0.05 \mathrm{molL}^{-1}$ ascorbic acid was added to convert $\mathrm{Fe}^{3+}$ to $\mathrm{Fe}^{2+}$ ions that don't interfere. The effect of some other foreign ions that have little interfering effects $(\sim 12 \%)$ was completely removed by increasing the concentration of NaPAR.

TABLE 1. Effect of Ionic Strength on the Floatability of $2.0 \times 10^{-5} \mathrm{molL}^{-1}$ of $\mathrm{Co}$ (II) using $4.0 \times 10^{-4} \mathrm{molL}^{-1}$ of NaPAR and $2.0 \times 10^{-4} \mathrm{molL}^{-1} \mathrm{HOL}$ at $\mathrm{pH} 4$.

\begin{tabular}{ccc}
\hline Salt & Concentration, $\boldsymbol{\mu g m L}^{\mathbf{- 1}}$ & $\mathbf{F \%}$ \\
\hline \multirow{2}{*}{$\mathrm{NaCl}$} & 100 & 100 \\
& 100 & 99 \\
& 40 & 95 \\
$\mathrm{NaNO}_{3}$ & 100 & 100 \\
& 10 & 100 \\
& 40 & 99 \\
Oxalate & 10 & 99 \\
& 30 & 97 \\
\hline
\end{tabular}

Egypt. J. Chem. 61, No.4 (2018) 
TABLE 2. Effect of foreign ions on the floatability of $2.0 \times 10^{-5} \mathrm{molL}^{-1}$ of Co (II) using $4.0 \times 10^{-3} \mathrm{molL}^{-1} \mathrm{NaPAR}$ and $2.0 \times 10^{-4} \mathrm{molL}^{-1} \mathrm{HOL}$ at $\mathrm{pH} 4(\mathrm{n}=5)$.

\begin{tabular}{ccc}
\hline Foreign ions & Concentration $\left(\boldsymbol{\mu g m \mathbf { g L } ^ { - 1 } )}\right.$ & Recovery \% \\
\hline $\mathrm{K}(\mathrm{I})$ & 500 & 95 \\
$\mathrm{Na}(\mathrm{I})$ & 500 & 95 \\
$\mathrm{Ca}(\mathrm{II})$ & 500 & 93 \\
$\mathrm{Mg}(\mathrm{II})$ & 400 & 93 \\
$\mathrm{Al}(\mathrm{III})$ & 10 & 97 \\
$\mathrm{Fe}(\mathrm{III})$ & $0.5 \mathrm{~b}$ & 93 \\
$\mathrm{Cd}(\mathrm{II})$ & 0.5 & 96 \\
$\mathrm{Pd}(\mathrm{II})$ & 0.5 & 96 \\
$\mathrm{Hg}(\mathrm{II})$ & 0.5 & 94 \\
$\mathrm{Cu}(\mathrm{II})$ & 0.5 & 93 \\
$\mathrm{~Pb}(\mathrm{II})$ & 0.5 & 95 \\
$\mathrm{Ni}(\mathrm{II})$ & 0.5 & 96 \\
$\mathrm{Mn}(\mathrm{II})$ & 0.5 & 96 \\
\hline
\end{tabular}

a-After addition of $1 \mathrm{~mL}$ of $0.05 \mathrm{molL}^{-1} \mathrm{NaS}_{2} \mathrm{O}_{3}$ b- After addition of $1 \mathrm{~mL}$ of $0.05 \mathrm{molL}^{-1}$ ascorbic acid.

\section{Mechanism of flotation}

In the present study, the mechanism of flotation can be attributed to the formation of a hydrogen bonding between the hydrophilic part of HOL and the active sites in the ligand complex. This proposal has been based on the following findings: 1) the complex formed in scum layer has the same pink color as the complex formed in the aqueous solution; 2) The color intensity and absorbance of the scum layer were not affected by heating up to $80{ }^{\circ} \mathrm{C} ; 3$ ) The infrared spectra of the $\mathrm{Co}(\mathrm{II})$-NaPAR complex formed in the DDW is completely different from that formed in presence of oleic acid surfactant, (Fi. 8). The infrared spectrum of the $\mathrm{Co}(\mathrm{II})$-NaPAR complex formed in oleic acid layer (Fig. 8c) has $v(\mathrm{O}-\mathrm{H} . . \mathrm{O})$ vibrations representing the intermolecular hydrogen bonding are assigned at 1820, 2050 and $2400 \mathrm{~cm}^{-1}$. Vibration of carboxylate ion of oleic acid is confirmed by the presence of $v(\mathrm{C}=\mathrm{O})$ vibration at absorption bands $1710 \mathrm{~cm}^{-1}$ and the os COO- vibration is observed at $1462 \mathrm{~cm}^{-1}[16-20]$.

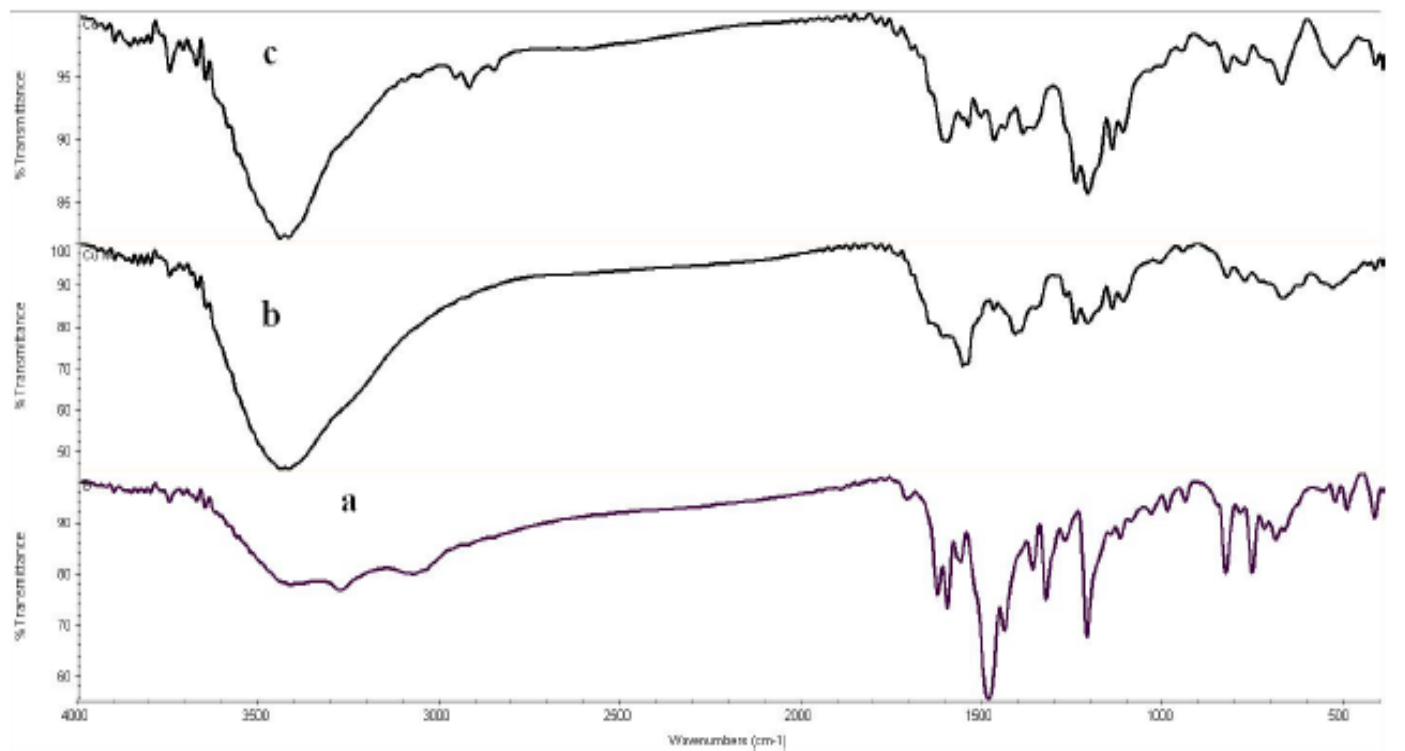

Fig. 8. Infrared spectra of a) $\mathrm{NaPAR}$ in $\mathrm{KBr}$, b) $\mathrm{Co}$ (II)-NaPAR isolated in aqueous solution in $\mathrm{KBr}$ and c) $\mathrm{Co}$ (II)NaPAR-HOL isolated in oleic acid in KBr. 


\section{Analytical Characteristics}

The Analytical Characteristics of the proposed flotation methodology are presented in Table 3 . Beer's law is obeyed in the concentration range of 0.01-0.32 $\mu \mathrm{g} \mathrm{Co}$ (II) per $\mathrm{mL}$ in the final solution. The molar absorptivity and Sandell's sensitivity were calculated to be $1.54 \times 10^{5} \mathrm{~L} \mathrm{~mol}^{-1} \mathrm{~cm}^{-1}$ and $0.0324 \mu \mathrm{g} \mathrm{cm}^{-2}$ at $510 \mathrm{~nm}$. The standard deviations of the absorbance measurements $(n=10)$, the limits of detection $(\mathrm{K}=3)$ and of quantification $(\mathrm{K}=10)$ of the method were established and recorded in Table 3. The relative standard deviation $(\mathrm{n}=10)$, was $1.5 \%$.

Table 4 represents a comparison between the molar absorptivity of the proposed method and other previously reported methods[22 - 29]. The higher sensitivity, represented by the high value of molar absorptivity, of the proposed method is notable, greater even than that of other previously reported methods.

\section{Applications}

\section{Water analysis}

Various concentrations of $\mathrm{Co}$ (II) ions were added to various water samples from different sources. The flotation procedures were applied for the determination of the recovery of the analyte in these water samples. The recovery percentage is greater than $100 \%$ (Table 5). The results of the present flotation method for $\mathrm{Co}(\mathrm{II})$ are compared with those gained upon using the well-known ammonium pyrrolidinedithiocarbamate/ methyl isobutyl ketone (APDC/MIBK) solvent extraction method using the $F$-value test for $\mathrm{P}=0.05$ and $\mathrm{n}=$ 5 (4 degree of freedom), for precision. The results in Table 6 show that the $F$-values $(2.78-4.15)$ are below the theoretical values. This means that the proposed flotation procedure is precise.

\section{TABLE 3. Analytical characteristics.}

\begin{tabular}{cc}
\hline Parameter & Value \\
\hline Beer's law limit $\left(\mu \mathrm{g} \mathrm{mL}^{-1}\right)$ & $0.01-0.32$ \\
Ringbom optimum range $\left(\mu \mathrm{g} \mathrm{mL}^{-1}\right)$ & $0.03-0.36$ \\
Molar absorptivity $\left(\mathrm{L} \mathrm{mol}^{-1} \mathrm{~cm}^{-1}\right)$ & $1.54 \times 10^{5}$ \\
Sandell's sensitivity $\left(\mu \mathrm{g} \mathrm{cm}^{-2}\right)$ & 0.0324 \\
Detection limit $\left(\mathrm{ng} \mathrm{mL}^{-1}\right)$ & 3.09 \\
Quantification limit $\left(\mathrm{ng} \mathrm{mL}^{-1}\right)$ & 10.3 \\
Ringbom optimum range $\left(\mu \mathrm{gL}^{-1}\right)$ & $0.01-0.3$ \\
$\lambda$ max, nm & 510 \\
Stoichiometry $, \mathrm{L}: \mathrm{M}$ & $2: 1$ \\
\hline
\end{tabular}

aJob's method[21]

TABLE 4. Comparison of the sensitivity for spectrophotometric determination of cobalt (II).

\begin{tabular}{|c|c|c|c|c|}
\hline Reagent & $\begin{array}{c}\lambda_{\max }, \\
\mathrm{nm}\end{array}$ & $\begin{array}{c}\varepsilon^{\times 10^{4}} \\
\left(\mathrm{~L} \mathrm{~mol}^{-1}\right. \\
\left.\mathrm{cm}^{-1}\right)\end{array}$ & Medium & Ref \\
\hline 2quinolylazo)5dimethyl amino aniline)2 & 625 & 14.3 & $\begin{array}{c}\text { Isopentyl } \\
\text { alcohol }\end{array}$ & {$[22]$} \\
\hline Nitroso R(sodium-1-nitroso-2-hydroxy naphthalene -3.6 disulphonate) & 550 & 2.45 & Aqeous & [23] \\
\hline 2-Diethylamino-5-nitroso-1,4,5,6-tetrahydro pyrimidine-4,6-dione & 385 & 6.3 & Acidic & {$[24]$} \\
\hline Nitroso R salt & 415 & 3.5 & heating & {$[25]$} \\
\hline 2Thiazolylazo)2naphthol)1 & 572 & 262 & $\begin{array}{l}\text { Immobilized } \\
\text { on C } 18 \\
\text { bonded silica }\end{array}$ & {$[26]$} \\
\hline (2-(3,5 dibromopyridyl)azo)-5- Dimethylaminobenzoiccid & 673 & 15.5 & Extraction & {$[27]$} \\
\hline 2-(2-Thiazolylazo)-4-methyl-5(sulfomethylamino)benzoic acid & 655 & 11.3 & aqueous & {$[28]$} \\
\hline Potassium teterahydrofurylxanthate & 350 & 3.43 & extraction & {$[29]$} \\
\hline 4-(2 Pyridylazo) resorcinol & 510 & 154 & Oleic acid & $\begin{array}{r}\text { Present } \\
\text { study }\end{array}$ \\
\hline
\end{tabular}

Egypt. J. Chem. 61, No.4 (2018) 
TABLE 5. Recovery of Co(II) from different water samples(n=5).

\begin{tabular}{cccc}
\hline \multirow{2}{*}{ Water sample } & \multicolumn{2}{c}{$\mathbf{C o}(\mathbf{I I})\left(\boldsymbol{\mu g m L ^ { - 1 } )}\right.$} & \multirow{2}{*}{ Recovery \% } \\
\cline { 2 - 4 } & added & measured & --- \\
Tap water & 0.00 & 0.07 & 100.3 \\
(our laboratory) & 5.00 & 5.015 & 99.5 \\
Nile water & 10.00 & 9.95 & --- \\
(Sherbin city) & 0.00 & 0.50 & 109.3 \\
& 5.00 & 5.465 & 104.7 \\
Sea water & 10.00 & 10.470 & --- \\
(Ras El-Barr city) & 0.00 & 1.25 & 123.7 \\
& 5.00 & 6.185 & 111.1 \\
\hline
\end{tabular}

TABLE 6. Determination of $\mathrm{Co}(\mathrm{II})$ in $\mu \mathrm{gL}^{-1}$ in natural water samples by the present flotation technique and the standard APDC/MIBK solvent extraction methods (SE) $(n=5$ for both) methods.

\begin{tabular}{|c|c|c|c|c|c|}
\hline \multirow{2}{*}{ Sample } & \multicolumn{2}{|c|}{ Flotation } & \multicolumn{2}{|c|}{ Solvent extraction (SE) } & \multirow[t]{2}{*}{ F-value a } \\
\hline & $\mathrm{Co}(\mathrm{II})$ & RSD, \% & $\mathrm{Co}(\mathrm{II})$ & RSD, \% & \\
\hline $\begin{array}{l}\text { Tap water } \\
\text { (Our lab. Mansoura City) }\end{array}$ & 0.07 & 1.0 & 0.06 & 2.3 & 2.78 \\
\hline $\begin{array}{l}\text { Waste water } \\
\text { (Meat Anter, Talkha) }\end{array}$ & 1.35 & 2.0 & 1.40 & 2.8 & 4.10 \\
\hline $\begin{array}{l}\text { Nile River water } \\
\text { (Sherbin City) }\end{array}$ & 0.50 & 1.5 & 0.56 & 3.5 & 2.85 \\
\hline $\begin{array}{l}\text { Lake water } \\
\text { (Manzalah) }\end{array}$ & 0.35 & 1.8 & 0.40 & 0.8 & 3.46 \\
\hline $\begin{array}{l}\text { Sea water } \\
\text { (RasElbar city) }\end{array}$ & 1.25 & 2.5 & 1.30 & 1.5 & 4.15 \\
\hline
\end{tabular}

${ }^{\mathrm{a}} \mathrm{F}$-value for $\mathrm{P}=0.05$ and $\mathrm{n}=5(4$ degree of freedom $)=5.05$.

\section{Analysis of ore samples $T$}

Two reference standard materials (lead-zinc sulphide ore-OCrO (COD 161-96) and Steel scrap sample) were analyzed. The results are given in Table 7. There is no significant difference between the results obtained by the proposed method and the certified samples. The relative standard deviation (as a precision) is less than 5\%.

Analysis of pharmaceutical samples

The flotation followed by spectrophotometric and FAAS determination was applied to determine $\mathrm{Co}(\mathrm{II})$ in some vitamin $\mathrm{B}_{12}$ samples. The experimental results agreed well with the given reported values (Table 8).

\section{Application to synthetic mixtures}

The results obtained in Table 9 show that high separation recovery of the $\mathrm{Co}$ (II) could be obtained from samples containing different synthetic mixtures.

\section{Conclusion}

The proposed flotation is a simple technique using a simple flotation cell. The method is advantageous to many of the separation techniques previously reported for the spectrophotometric determination of cobalt. The method has high molar absorptivity value and low detection limit. It is sensitive, accurate, and can tolerate various interfering ions. The use of large flotation cells allowed the determination of cobalt(II) from water samples having large volume with a high preconcentration factor. The flotation mechanism is proposed. The method is easy to perform for the determination of cobalt concentrations in natural waters and pharmaceutical samples. 
TABLE 7. Comparative results for analysis of $\mathrm{Co}(\mathrm{II})$ at $\mathrm{pH} 4$ in some ore samples in presence of $4 \times 10^{-2} \mathrm{molL}^{-}$ ${ }^{1}$ NaPAR using $2 \times 10^{-4} \mathrm{molL}^{-1} \mathrm{HOL}$

\begin{tabular}{|c|c|c|c|c|c|c|}
\hline \multirow[b]{2}{*}{ Sample name } & \multicolumn{2}{|c|}{ Co(II)ppm } & \multirow{2}{*}{$\begin{array}{l}\text { Abs. } \\
\text { error }\end{array}$} & \multirow{2}{*}{$\begin{array}{c}\mathbf{R} . \\
\text { error }\end{array}$} & \multirow[b]{2}{*}{ SD } & \multirow[b]{2}{*}{ RSD, \% } \\
\hline & Certificate & found & & & & \\
\hline Lead-Zinc sulfide ore & 1.0 & 1.0 & 0.0 & 0.0 & 0.017 & 1.7 \\
\hline Steel scrap sample & 0.8 & 0.81 & 0.01 & 0.013 & 0.024 & 3.0 \\
\hline
\end{tabular}

TABLE 8. Statistical evaluation for analysis of some pharmaceutical vitamin samples after flotation (n=5). Comparison of experimental mean $(\bar{x})$ mg/ampule with true value $(\mu)$, by $|t|_{1}$ test

\begin{tabular}{cccccc}
\hline Sample & $(\overline{\mathrm{X}})$ & $\boldsymbol{\mu}$ & $\mathbf{S}$ & $|\mathrm{t}|_{1}$ & RSD \\
\hline No. $1^{\mathrm{a}}$ & 0.99 & 1.0 & 0.01 & 0.49 & 1.98 \\
No. $2^{\mathrm{b}}$ & 0.98 & 1.0 & 0.02 & 0.75 & 2.04 \\
\hline
\end{tabular}

${ }^{\mathrm{a} D e p o v i t} \mathrm{~B}_{12}$ (AMRIYA Pharm) ampule. ${ }^{\mathrm{b} B e t o l v e x(M e n a p h a r m) ~ a m p u l e . ~}$

$(\bar{X})$ : experimental value, $(\mu)$ true value; $|t|_{1}$ for $P=0.05$ and $n=5$ (4 degree of freedom $)=2.78$. R.S.D., \%: Relative standard deviation.

TABLE 9. Separation via flotation of Co(II) from synthetic mixtures. (n=5)

\begin{tabular}{ccccc}
\hline & \multicolumn{2}{c}{ Co $(\mathbf{I I})(\boldsymbol{\mu g} / \mathbf{m L})$} & \multirow{2}{*}{$\mathbf{R}$} & \multicolumn{2}{c}{ R.S.D } \\
\cline { 2 - 5 } Synthetic mixtures composition & added & found & & \% \\
\hline \multirow{2}{*}{$\mathrm{Zn}(\mathrm{II})(5 \mu \mathrm{g} / \mathrm{mL})+\mathrm{Ni}(\mathrm{II})(5 \mu \mathrm{g} / \mathrm{mL})$} & 2.00 & 1.97 & 98.50 & 0.81 \\
$\mathrm{Hg}(\mathrm{II})(5 \mu \mathrm{g} / \mathrm{mL})+\mathrm{Pb}(\mathrm{II})(5 \mu \mathrm{g} / \mathrm{mL})$ & 5.00 & 4.96 & \multicolumn{2}{c}{99.201 .25} \\
$\mathrm{Zn}(\mathrm{II})(3 \mu \mathrm{g} / \mathrm{mL})+\mathrm{Ni}(\mathrm{II})(3 \mu \mathrm{g} / \mathrm{mL})+\mathrm{Cr}(\mathrm{III})(3 \mu \mathrm{g} /$ & 3.00 & 2.91 & 95.67 & 0.48 \\
$\mathrm{~mL})$ & 5.00 & 2.87 & 98.80 & 1.03 \\
$\mathrm{Hg}(\mathrm{II})(3 \mu \mathrm{g} / \mathrm{mL})+\mathrm{Pb}(\mathrm{II})(3 \mu \mathrm{g} / \mathrm{mL})+\mathrm{Bi}(\mathrm{III})(3 \mu \mathrm{g} /$ & 3.00 & 2.92 & 97.00 & 0.41 \\
$\mathrm{~mL})$ & 5.00 & 4.89 & 99.00 & 0.70 \\
& & & 97.33 & 1.05 \\
\hline
\end{tabular}

\section{References}

1. Hoai N.T., Yoo D. and Kim D., Batch and column separation characteristics of copper-imprinted porous polymer micro-beads synthesized by a direct imprinting method. J. Hazard. Mater. 173, 462-467 (2010).

2. Yamada K., Cobalt: Its Role in Health and Disease. Yamada, Kazuhiro (2013). "Chapter 9. Cobalt: Its Role in Health and Disease". In Astrid Sigel, Helmut Sigel and Roland K. O. Sigel. Interrelations between Essential Metal Ions and Human Diseases. Metal Ions in Life Sciences 13. Springer. pp. 295320 (2013).

Egypt. J. Chem. 61, No.4 (2018)
3. Jankowski K., Yao J., Kasiura K., Jackowska A. and Sieradzka A., Multielement determination of heavy metals in water samples by continuous powder introduction microwave-induced plasma atomic emission spectrometry after preconcentration on activated carbon. Spectrochim. Acta Part B. 60, 369-375 (2005).

4. Cerutti S., Moyano S., Marrero J., Smichowski P. and Martinez L.D., On-line preconcentration of nickel on activated carbon prior to its determination by vapor generation associated to inductively coupled plasma optical emission spectrometry. JAAS 20, 559-561 (2005). 
5. Doner G., Ege A., Determination of copper, cadmium and lead in seawater and mineral water by flame atomic absorption spectrometry after coprecipitation with aluminum hydroxide. Anal. Chim. Acta 547, 14-17 (2005).

6. Tewari P.K., Singh A.K. Preconcentration of lead with Amberlite XAD-2 and Amberlite XAD-7 based chelating resins for its determination by flame atomic absorption spectrometry. Talanta 56, 735-744 (2002).

7. Gholivand M.B., Mohammadi M., Khodadadian M., Rofouei M.K., Novel platinum (II) selective membrane electrode based on. Talanta 78, 922-928 (2009).

8. Li X., Ma X., Huang M., Lead (II) Ion-selective electrode based on polyaminoanthraquinone particles with intrinsic conductivity. Talanta 78, 498-505 (2009).

9. Camino M., Bagur M.G., Sa M., Multivariate optimization of solvent extraction of Cd ( II ), Co ( II ), Cr ( VI ), Cu ( II ), Ni ( II ), Pb ( II ) and Zn ( II ) as dibenzyldithiocarbamates and detection by AAS. JAAS. 16, 638-642 (2001).

10. Luiz E., Roldan S., Fernanda M., Simultaneous preconcentration of copper, zinc, cadmium, and nickel in water samples by cloud point extraction using 4- ( 2-pyridylazo ) -resorcinol and their determination by inductively coupled plasma optic emission spectrometry. J Hazard. Mater. 171, 1133-1138 (2009).

11. Kabil M.A., Akl M.A., Khalifa M.E., Selective Flotation - Spectrophotometric Procedure for the Trace Analysis of Palladium ( II ) in Different Matrices. Anal. Sci. 15, 433-438 (1999).

12. Akl M.A., Dalia S., Isamil Bakir Geragh, Ahmed A. El-Asmy, Flotation separation and spectrophotometric determination of $\mathrm{Sc}^{3+}$ in certified materials and different water resources. $J$ Sci. Res. Rev. 3, 8-17 (2014).

13. Kabil M.A., AKl M.A., Abdallah A.M., Ismail D., Selective Separation - Flotation of Hafnium from Zirconium and Their Determination in Real Samples. Anal.Sci.16, 3-8 (2000).

14. Ghazy S.E., Kabil M., Determination of Trace copper in Natural Waters after Selective Separation by Flotation. Bull Chem. Soc.Jap.67, 2098-2102 (1994).

15. Lemlich R., Adsorptive Bubble Separation Techniques, Academic Press,New York (1972).
16. Mostafa M.M., Spectrochim. Acta, A 66480 (2007).

17. Rodrìguez-ArgüellesM.C.,FerrariM.B., Bisceglie F., Pelizzi C., Pelosi G., Pinelli S. and Sassi M.; $J$. Inorg. Biochem., 98, 313 (2004).

18. Sathyanarayana D.N. and Nicholls D., Spectrochim. Acta, A 34, 263 (1978).

19. Wang B.-D.,. Yang Z.-Y, Zhang D.-W. and WangY; Spectrochim. Acta, A 63 213.6, 1917-1923 (2006).

20. Job P. H. C., Seances Acad Sci. 180, 928 (1925).

21. Hu, Q., Yang, G., Dong, X., Yin, J., Study on the Solid Phase Extraction and Spectrophotometric Determination of Cobalt with 2-(2-Quinolylazo)-5Diethylaminoaniline. Turk. J. Chem. 28, 611-619 (2004).

22. Zhang, L., Terada, K., Spectrophotometric Determination of Cobalt(II) in Water after Preconcentration by Sorption of Its Nitroso $\mathrm{R}$ Complex with Poly(chlorotrifluoroethylene) Resin. Anal. Sci. 10,161-165 (1994).

23. Tsuchiya, M., Iwanami, Y., Spectrophotometric Determination of Cobalt(III) with 2-Diethylamino5-nitroso-1,4,5,6-tetrahydropyrimidine 4,6-dione. Anal. Sci. 8, 869-872.26 (1992).

24. Marczenko Z., Spectrophotometric Determination of Elements. (Wiley, New York) (1976).

25. Teixeira L.S.G., Costa A.C.S., Assis J.C.R., Ferreira S.L.C., Korn M., Solid Phase Spectrophotometry for the Determination of Cobalt in Pharmaceutical Preparations. Mikrochim. Acta.137, 29-33 (2001).

26. Katami T., Hayakawa T., Extraction and Spectrophotometric Determination of Cobalt in Coal Fly Ashes Using 2- [ 2- ( 3 , 5- Di bromopyridyl) azo ] -5 -d imethylamino benzoic Acid. 108, 864-869 (1983).

27. Wada H., Ishizuki T., Kodama H., Najakawa G., Spectrophotometric Determination of Cobalt in Steel with 2- ( 2-Thiazolylazo ) -4-methyl-5- ( sulfomethylamino ) benzoic Acid ( TAMSMB ). Analyst 80,139-149 (1983).

28. Hussain M.F., Bansal R.K., Puri B.K., Satake M., Spectrophotometric determination of cobalt, nickel and iridium after coprecipitation of their tetrahydrofurfurylxanthates on to microcrystalline naphthalene. Analyst 110, 1131-1136 (1985).

(Received 24/4/2018; accepted 23/5/2018)

Egypt. J. Chem. 61, No.4 (2018) 


\title{
والثنية بسيطة وخضر اء للفصل بالتعويم والتقدير الطيفي للكوبلت الثنائي في العينات الدوائية

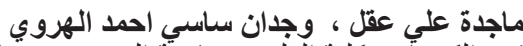

\begin{abstract}
في هذه الدراسة ، تم استخدام تقنية خضر اء وبسيطة للتركيز المسبق ، و التعويم و الكثف عن الطيف الضوئي

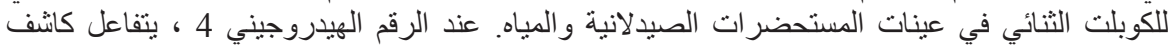

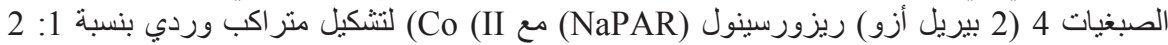
(M: L)

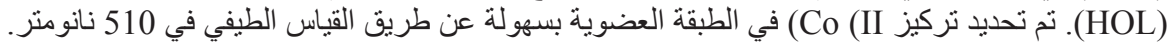

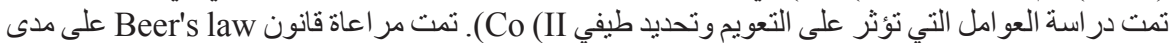

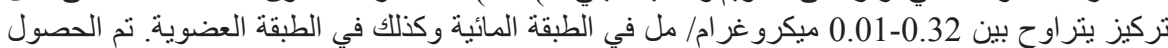

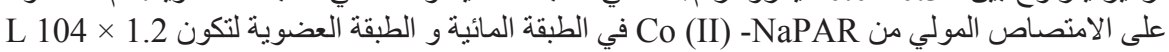

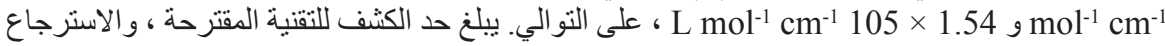

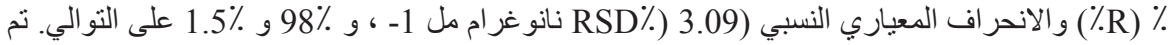

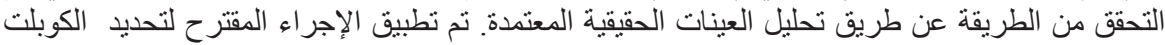

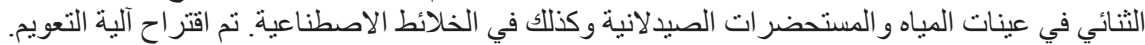

